\title{
The Time of the Primary Varicella Zoster Virus Infection in Previously Healthy Children with Herpes Zoster: Is It Important?
}

\section{Öncesinde Sağlıklı Olan Herpes Zosterli Çocuklarda Primer Varisella Zoster Virüs Enfeksiyonunun Zamanı: Önemli mi?}

\author{
Dilek Yılmaz Çiftdoğan ${ }^{1}$ \\ 'Department of Pediatric Infectious Diseases, Katip Celebi University School of Medicine, Izmir, Turkey
}

\begin{abstract}
Objective: Herpes zoster $(\mathrm{HZ})$ is rare in children. Previous studies have reported that $\mathrm{HZ}$ is more common among immune-supressed children. However, this disease can also be seen in healthy children. Exposure to varicella zoster virus (VZV) in the early stages of life could be an important determinant for $\mathrm{HZ}$ development. In the present study, 17 healthy children who developed $\mathrm{HZ}$ were evaluated. In particular, the age at onset of $\mathrm{HZ}$ and the time interval between primary infection and $\mathrm{HZ}$ were interpreted in children who had been chickenpox within the first year of life and who had been chickenpox after the first year of life.

Material and Methods: In this retrospective study, we evaluated 19 children who were admitted to Gaziantep Pediatric Hospital, Departments of Pediatric Infectious Diseases, between July 2012 and June 2013 and diagnosed with HZ. Of these children who had immunsupression such as immunodeficiency, malignancy and other immunodeficiency conditions were excluded from the study.

Results: We evaluated 19 children who were diagnosed with $\mathrm{HZ}$. Two children with $\mathrm{HZ}$ were excluded from the study due to their immunsupressive states. As a result, we evaluated 17 healthy children with $\mathrm{HZ}$ in this study. The median age of the applicants was 9 years. Eight of them had been chickenpox within the first year of life. One patient was exposed to VZV in the uterine periods ( $32^{\text {nd }}$ gestation week). The most frequent involvement was in thoracic dermatome $(n=9,52.9 \%)$. The median age at onset of $\mathrm{HZ}$ was significantly lower in children who had been chickenpox within the first year of life than in children who had been chickenpox after the first year of life (7.5 years, 13.2 years,
\end{abstract}

Özet

Giriş: Herpes zoster (HZ), çocuklarda ender görülmektedir. Yapılmış çalışmalarda, immünsüpresif çocuklarda daha sık görüldüğü belirtilmiştir. Ancak, sağlıklı çocuklarda da görülebilmektedir. Yaşamın erken evrelerinde varisella zoster virüsü (VZV)'ne maruz kalmak HZ gelişiminde önemli bir belirteç olabilir. Bu çalışmada $\mathrm{HZ}$ gelişen 17 sağlıklı çocuk değerlendirildi. Özellikle $\mathrm{HZ}$ başlangıç yaşı ve birincil enfeksiyon ile $\mathrm{HZ}$ arasındaki zaman aralığı, yaşamın ilk yıllarında suçiçeği olan ve hayatının ilk yılından sonra suçiçeği olan çocuklarda değerlendirildi.

Gereç ve Yöntemler: Bu retrospektif çalışmada, Temmuz 2012 ile Haziran 2013 tarihleri arasında Gaziantep Çocuk Hastanesi, Çocuk Enfeksiyon Hastalıkları Bölümünde takip edilen $\mathrm{HZ}$ tanılı 19 çocuk değerlendirildi. Bu çocuklar arasından immünyetmezlik malignitesi ve diğer immünyetmezlik durumları gibi immünsüpresyonu olan çocuklar çaıışmadan çıkarıldı.

Bulgular: Çalışma döneminde $\mathrm{HZ}$ tanısı alan 19 çocuk değerlendirildi. HZ'li 2 çocuk immünsüpresif durum nedeniyle çalışmadan çıkarıldı. Sonuç olarak, bu çalışmada HZ tanılı 17 sağlıklı çocuk değerlendirildi. Başvurudaki ortanca yaş 9 yıl idi. Olgulardan 8'i yaşamlarının ilk yılında suçiçeği geçirmişti. Bir olgu ise uterin dönemde (32. gestasyon haftası) VZV maruz kalmıştı. En sık tutulum torasik dermatomda idi ( $n=9$, \%52.9). HZ başlangıç yaşı ortanca değeri, yaşamlarının ilk yılında suçiçeği olan çocuklarda, yaşamlarının ilk yılı sonrasında suçiçeği olan çocuklara göre anlamlı olarak daha düşüktü (sırasıyla; 7.5 yıl, 13.2 yıl, $\mathrm{p}=0.001$ ). Ayrıca, primer enfeksiyonu ile $\mathrm{HZ}$ arasındaki zaman aralığı
Correspondence Address / Yazışma Adresi

Dilek Yılmaz Çiftdoğan

İzmir Tepecik Eğitim ve Araştırma Hastanesi, Çocuk Sağlığı ve Enfeksiyon Hastalıkları, İzmir-Türkiye

E-mail: drdilekyilmaz@hotmail.com OCopyright 2017 by Pediatric
Infectious Diseases Society -Available online at www.cocukenfeksiyon.org OTelif Hakkı 2017 Çocuk Enfeksiyon Hastalıkları Derneği -Makale metnine www.cocukenfeksiyon.org web sayfasından ulaşılabilir 
respectively, $p=0.001$ ). Also, the time interval between primary infection and $\mathrm{HZ}$ was significantly lower in children who had chickenpox within the first year of life (80 months, 131 months, respectively, $p=0.003$ ).

Conclusion: The time of the primary VZV infection is the determining risk factor for herpes zoster in healthy children. Additionally, early exposure to VZV may be associated with early development of $\mathrm{HZ}$ and shorter time interval between primary VZV infection and $\mathrm{HZ}$.

Keywords: Herpes zoster, healthy, child

\section{Introduction}

Varicella zoster virus (VZV) infection causes two clinically forms of the disease. Primary infection with VZV results in varicella. Herpes zoster develops as a result of the reactivation of latent VZV infection within the dorsal root ganglia. This clinically form is characterized by vesicular lesions clustered in the dermatomal distribution of sensory nerves (1).

Herpes zoster is rare during childhood. It can occur any time after primary infection, however, the incidence rates increase with age, probably due to the decrease in specific cell mediated immunity $(1,2)$. HZ is not rare in children with cellular immune deficiency. But, it may be seen in children without immunosuppression (1,3-5).

Age is an important determining factor for the development of HZ. The primary VZV infection time can be an important determinant for the development of $\mathrm{HZ}$. Children infected with VZV in the intrauterine period or in the early stage of life may be at risk of developing $\mathrm{HZ}$ due to a diminished development of immunity to primary infection at this stage $(4,5)$.

In the present paper, 17 healthy children who developed $\mathrm{HZ}$ were presented to emphasize the epidemiological and clinical features of $\mathrm{HZ}$. In particular, the age at onset of $\mathrm{HZ}$ and the time interval between primary infection and $\mathrm{HZ}$ were interpreted in children who had been varicella within the first year of life and who had been varicella after the first year of life.

\section{Materials and Methods}

In this retrospectice study, we evaluated 19 children who were diagnosed with $\mathrm{HZ}$ admitted to Gaziantep Pediatric Hospital, Departments of Pediatrics Infectious Diseases, between July 2012 and June 2013. Clinical and demographic data were recorded. Laboratory data such as complete blood count, lymphocyte subset count, immunoglobulin levels ( IgA, IgM, IgG, IgE), human immunodeficiency virus (HIV) antibodies, anti-VZV IgM and IgG results were evaluated. Children with $\mathrm{HZ}$ who had immunodeficiency, recent trauma, surgery, malignancy, HIV infection and other immunodeficiency states da yaşamlarının ilk yılında suçiçeği olan çocuklarda anlamlı olarak daha düşüktü (sırasıyla; 80 ay, 131 ay, $p=0.003$ ).

Sonuç: Primer VZV enfeksiyonunun zamanı, sağlıklı çocuklarda HZ gelişimi için belirleyici bir risk faktörüdür. Ayrıca, VZV'ye erken maruziyet, $H Z$ 'nin daha erken gelişimi ve de primer VZV enfeksiyonu ile $\mathrm{HZ}$ arasındaki zaman aralığının daha kısa olması ile ilişkili olabilir.

Anahtar Kelimeler: Herpes zoster, sağlıklı, çocuk

such as, transplantation or immunosuppressive therapy were excluded from the study. In addition, history of the VZV vaccination was evaluated.

SPSS for Windows 19.0 (Inc., USA) was used for statistical analyses. Medians were used to describe variables with abnormal distribution. The difference between median values were tested by Mann-Whitney $U$ test. A value of $p<0.05$ was considered to be significant.

\section{Results}

In the study period, 2 children with $\mathrm{HZ}$ who was diagnosed with immunodeficiency and 1 child with $\mathrm{HZ}$ who was diagnosed with leukemia were excluded from the study. As a result, we evaluated 17 healthy children with $\mathrm{HZ}$ in the present study. The demographic and clinical characteristics of the children were summarised in Table 1. Ten of them were boys (58.8 $\%)$. The median age at the onset of the disease was 9 years (4-17 years). The median age when exposed to VZV was 13 months. Eight of them had varicella within the first year of life. One case with $\mathrm{HZ}$ had no history of varicella. However, it was detected that the mother of this case had varicella during the 32 nd week of gestation. None of them had received antiviral treatment at that time.

The most common involvement was thoracic dermatome $(n=9,52.9 \%)$. Of the children, five (29.4\%) had lumbar, 2 (11.7\%) had cervical, and 1 (5.8\%) had sacral involvement. None of them had facial nerve involvement and no more than one dermatome involvement.

Pruritus was the most common complaint in children with $H Z(n=14,82.8 \%)$. The other complaints at the presentation were pain $(n=12,70.5 \%)$ and fever $(n=4,23.5 \%)$. Regional enlarged lymph nodes were noted in 3 children (17.6\%) at the time of disease presentation. Post-herpetic neuralgia and post herpetic itching were not observed in any of them. Complications developed in the 5 (29.4\%) of the children. The complications observed were secondary bacterial infection (3 cases, $17.6 \%)$, severe ulceration (1 case, 5.9\%) and depigmantation (1 case, 5.9\%).

Intravenous acyclovir was administered to seven children with moderate to severe symptomatic rash. Three adolescents 


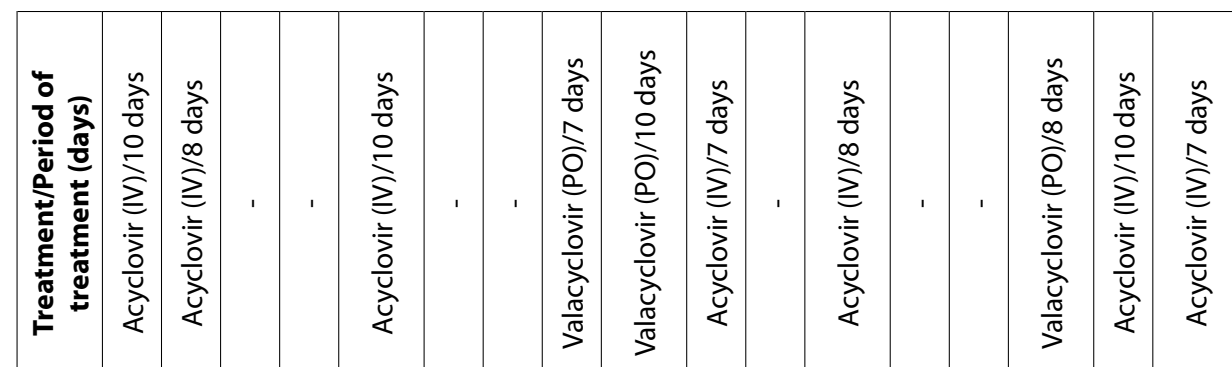

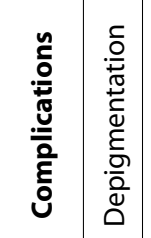

\section{高}

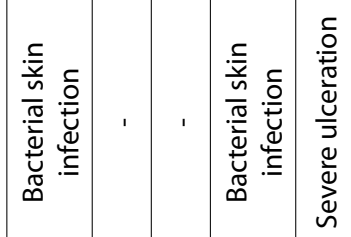

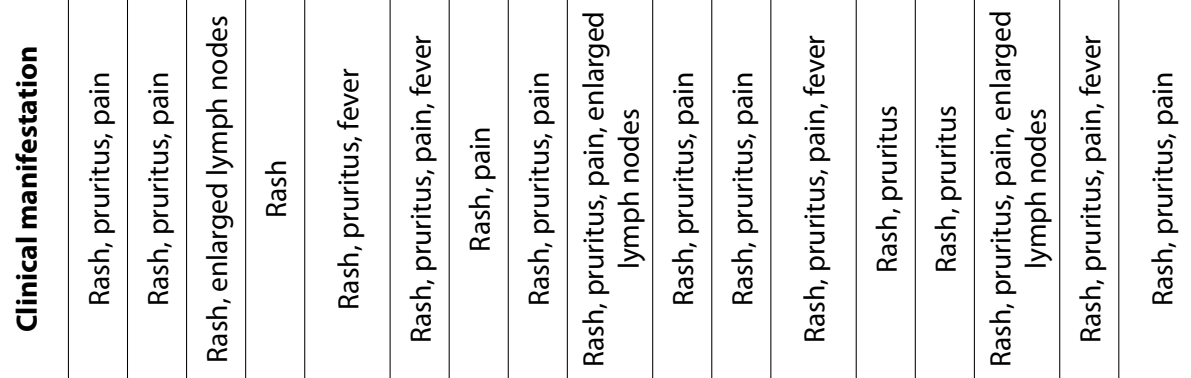

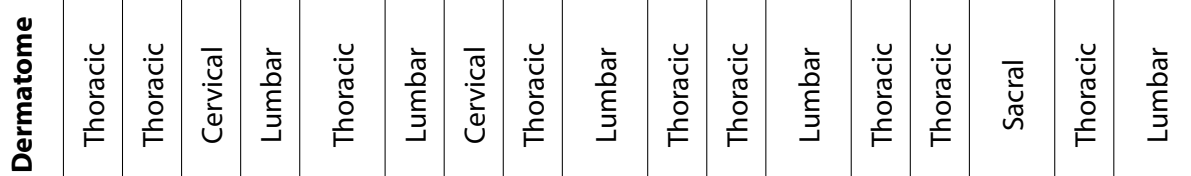

童
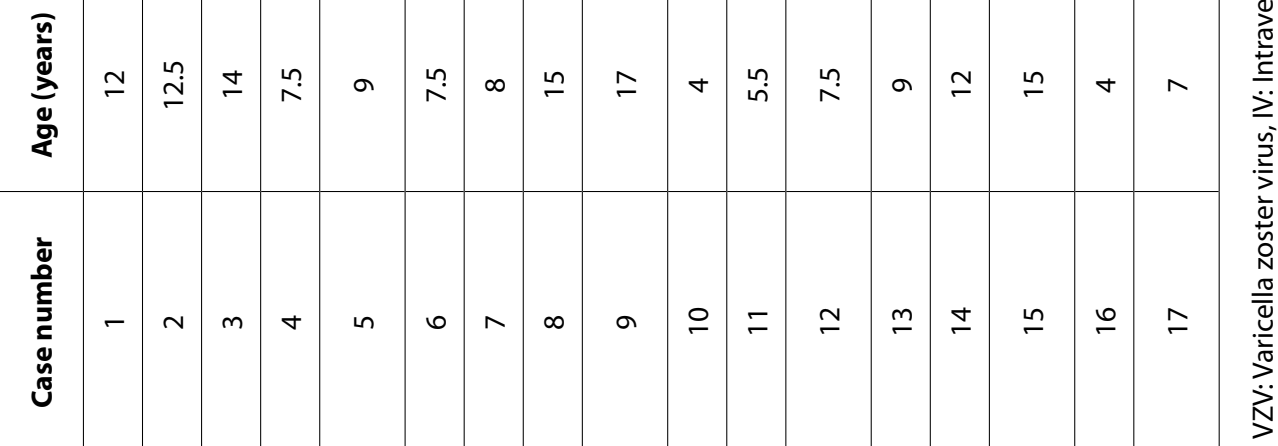


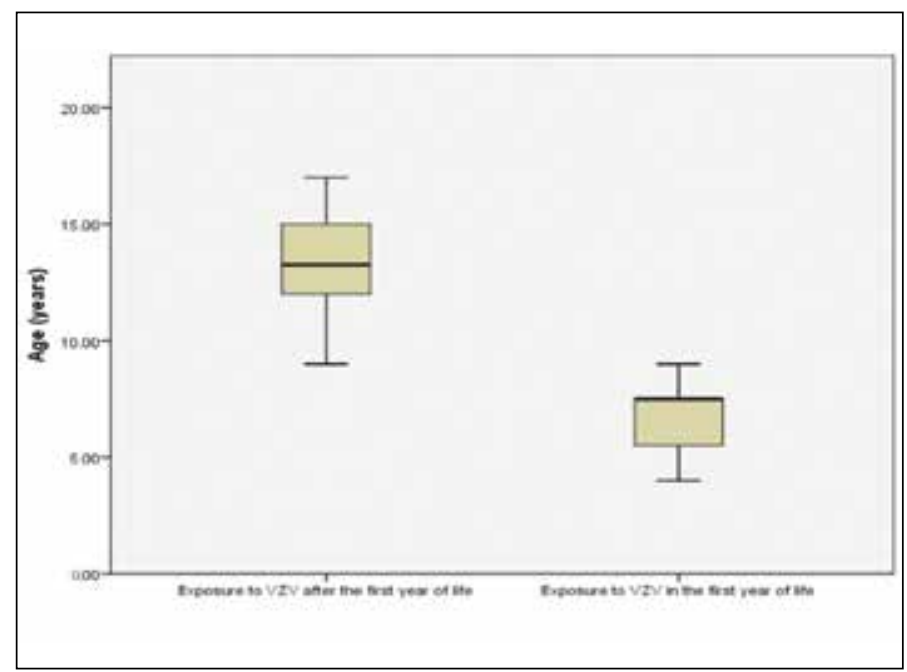

Figure 1. The onset time of herpes zoster $(\mathrm{HZ})$ in children who had varicella after the first year of life and within the first year of life.

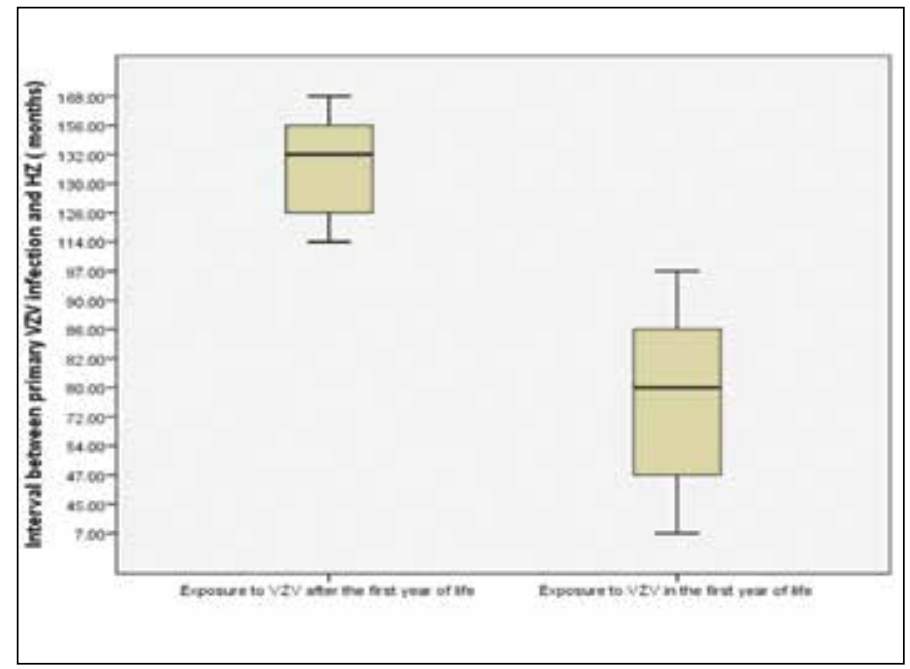

Figure 2. The time interval between primary varicella zoster virus (VZV) infection and herpes zoster $(\mathrm{HZ})$ in children who had varicella after the first year of life and within the first year of life.

with moderate to severe symptomatic rash received oral valacyclovir. Seven children did not get treatment because of the healing lesions during the first examination (Table 1). The resolution period for cutaneous lesions was between 5 to 14 days.

The median age at onset of $\mathrm{HZ}$ was lower in children who had varicella within the first year of life compared to children who had varicella after the first year (respectively, 7.5 years, 13.2 years, $p=0.001$ ) (Table 2) (Figure 1). The time interval between primary infection and $\mathrm{HZ}$ was 80 months in children who had varicella in the first year. This was 131 months in children who had varicella after the first year of life (Table 2) (Figure 2). This time interval was significantly lower in children who had varicella within the first year of life $(p=0.003)$.
Table 2. The onset time of herpes zoster $(\mathrm{HZ})$ and the time interval between primary varicella zoster virus (VZV) infection and $\mathrm{HZ}$ in children who had been varicella after the first year of life and who had been varicella in the first year of life

\begin{tabular}{|l|c|c|c|}
\hline & $\begin{array}{c}\text { Children who } \\
\text { had been } \\
\text { varicella after } \\
\text { the first year of } \\
\text { life (n= 8) }\end{array}$ & $\begin{array}{c}\text { Children who } \\
\text { had been } \\
\text { exposed to VZV } \\
\text { in the first year } \\
\text { of life (n= 9) }\end{array}$ & p \\
\hline $\begin{array}{l}\text { The onset time } \\
\text { of HZ (years) }\end{array}$ & 13.2 (3)years & 7.5 (3) years & 0.001 \\
\hline $\begin{array}{l}\text { The interval } \\
\text { between primary } \\
\text { varicella zoster } \\
\text { virus (VZV) } \\
\text { infection and HZ } \\
\text { (months) }\end{array}$ & 131 (33) months & 80 (42) months & 0.003 \\
\hline
\end{tabular}

\section{Discussion}

Age is an important determinant in the development of $H Z$. $H Z$ incidence increases with age $(6,7)$. The incidence is the lowest in the first 5 years of age (7). In the present pediatric study population, the median age at onset of $\mathrm{HZ}$ was 9 years.

In previous studies, it has been reported that $\mathrm{HZ}$ is more common among immunocompromised children, particularly in children with leukemia, lymphoma and HIV infection $(3,8,9)$. Primary infection induces specific antibody and specific $T$ cell mediated immunity. When specific $T$ cell-mediated immunity decreases, reactivation of latent infection leads to $\mathrm{HZ}$ (2). However, $\mathrm{HZ}$ can be seen in otherwise immunocompetent children. In our study group, no immunosupresed case was detected.

Various pediatric case series report that an important determinant for the development of $\mathrm{HZ}$ is having primary VZV infection during the first year of life $(4,5,10)$. Moreover, intrauterine VZV infection during pregnancy may also lead to an increased risk of developing $\mathrm{HZ}$ (3-5). This result could be explained by a diminished development of immunity against VZV at this early age (10). In our study, the median age for exposeing to VZV was 13 months. Eight patients had varicella in the first year. Among our patients, 1 case with $\mathrm{HZ}$ had no history of varicella. However, the mother of this case had a history of varicella during the $32^{\text {nd }}$ week of gestation.

Early exposure to VZV may be associated with early onset of $\mathrm{HZ}$ and shorter time interval between primary infection and $\mathrm{HZ}$. David et al. report that this time interval is 3.8 years in patients who had varicella within the first year of life and 6.2 years in patients who had varicella after the first year of life (11). In another paediatric study, the age at onset of varicella was significantly lower in immunocompetent children 
compared to immunosuppressed subjects with $\mathrm{HZ}$ (1.6 years vs. 4.6 years). The interval between varicella and $\mathrm{HZ}$ was $6.2 \pm$ 3.2 years in immunocompetent children (12). In this study, the median age at onset of $\mathrm{HZ}$ and the time interval between primary infection and $\mathrm{HZ}$ were lower in children who had been during the the first year of life.

Herpes zoster in healthy children is mildly symptomatic and usually shows a benign course (5). Pain, pruritus, fever, and lymphadenopathy are the most common symptoms in paediatric $\mathrm{HZ}$ patients. The most frequent dermatomal involvement is seen in thoracic site $(1,3,13)$. Most common complications are bacterial secondary infection, depigmentation and scarring $(1,5,12,13)$. In our patients, pruritus was the most common complaint. Other symptoms of the disease were pain and fever. In compliance with literature, the complications were secondary bacterial infection, severe ulceration and depigmentation. Thoracic dermatome was the most affected site.

The incidence of $\mathrm{HZ}$ in children is lower after vaccination (14). Weinmann $S$ et al. report that vaccinated children have a lower incidence of $\mathrm{HZ}$ compared to unvaccinated children (15). In the future, universal vaccination programs will probably impact $\mathrm{HZ}$ epidemiology, as has happened with varicella. In Turkey, VZV vaccination was added to the Turkish childhood national immunization programme in 2013. Children among the cases reviewed in this paper had not received VZV vaccination.

The goals of antiviral therapy in herpes zoster are to lessen the severity and duration of pain, to prevent new lesion formation, ensure rapid healing of lesions and to decrease viral shedding to reduce the risk of transmission $(16,17)$. Acyclovir has been shown to be effective for the treatment of $\mathrm{HZ}$ in healthy and immunocompromised patients $(1,18)$. Famciclovir and valacyclovir are effective oral agents for $\mathrm{HZ}$ (1). In the present study, antiviral treatment was administered to 10 children with moderate to severe symptomatic rash. However, 7 children did not get treatment because of the healing of the lesions during the first examination.

In conclusion, it was determined that $\mathrm{HZ}$ in immunocompetent children was not as mild as generally accepted. The time of the primary varicella infection may be indicative to the timing of HZ. Early exposure to VZV may be associated with early onset of $\mathrm{HZ}$ and shorter interval between primary varicella infection and $\mathrm{HZ}$.

Ethics Committee Approval: Due to the retrospective design of the employee, no ethics committee approval was received.

Informed Consent: Due to the retrospective design of the study, the patient was not approved.

Peer-review: Externally peer-reviewed.
Author Contributions: Concept - DYÇ; Design - DYÇ; Supervision - DYÇ; Data Collection and/or Processing - DYÇ; Analysis and/or Interpretation - DYÇ; Writing - DYÇ; Critical Review - DYÇ.

Conflict of Interest: The author has not reported a conflict of interest.

Financial Disclosure: There is no financial support in this study.

\section{References}

1. Arvin AM. Varicella zoster virus. In: Long SS, Pickering $L K$, Prober CG (eds). Principles and practice of pediatric infectious diseases. 3 ed. Philadelphia: Churchill Livingstone-Elsevier, 2008:1021-9.

2. Weinberg A, Lazar AA, Zerbe GO, et al. Influence of age and nature of primary infection on varicella-zoster virus-specific cell-mediated immune responses. J Infect Dis 2010;201:1024-30. [CrossRef]

3. Kurlan JG, Connelly BL, Lucky AW. Herpes zoster in the first year of life following postnatal exposure to varicella-zoster virus: four case reports and a review of infantile herpes zoster. Arch Dermatol 2004;140:126872. [CrossRef]

4. Feder HM Jr, Hoss DM. Herpes zoster in otherwise healthy children. Pediatr Infect Dis J 2004;23:451-7. [CrossRef]

5. Rodríguez-Fanjul X, Noguera A, Vicente A, et al. Herpes zoster in healthy infants and toddlers after perinatal exposure to varicella-zoster virus: $a$ case series and review of the litrature. Pediatr Infect Dis J 2010;29:574-6. [CrossRef]

6. Pinchinat S, Cebrián-Cuenca AM, Bricout H, Johnson RW. Similar herpes zoster incidence across Europe: results from a systematic literature review. BMC Infect Dis 2013;13:170. [CrossRef]

7. Donahue JG, Choo PW, Manson JE, Platt R. The incidence of herpes zoster. Arch Intern Med 1995;155:1605-9. [CrossRef]

8. Bacon GE, Oliver WJ, Shapiro BA. Factors contributing to severity of herpes zoster in children. J Pediatr 1965;67:763-71. [CrossRef]

9. Colebunders $R$, Mann JM, Francis $H$, et al. Herpes zoster in African patients: a clinical predictor of human immunodeficiency virus infection. J Infect Dis 1988;157:314-8. [CrossRef]

10. Terada K, Kawano S, Yoshihiro K, Morita T. Varicella-zoster virus (VZV) reactivation is related to the low response of VZV-specific immunity after chickenpox in infancy. J Infect Dis 1994;169:650-2. [CrossRef]

11. David TJ, Williams ML. Herpes zoster in infancy. Scand J Infect Dis 1979;11:185-6. [CrossRef]

12. Takayama $N$, Yamada $H$, Kaku H, Minamitani M. Herpes zoster in immunocompetent and immunocompromised Japanese children. Pediatr Int 2000:42:275-9. [CrossRef]

13. Guess HA, Broughton DD, Melton LJ, Kurland LT. Epidemiology of herpes zoster in children and adolescents: a population-based study. Pediatrics 1985;76:512-7. [CrossRef]

14. Hardy I, Gershon AA, Steinberg SP, LaRussa P; Varicella Vaccine Collaborative Study Group. The incidence of zoster after immunization with live attenuated varicella vaccine. A study in children with leukemia. N Engl J Med 1991;325:1545-50. [CrossRef]

15. Weinmann S, Chun C, Schmid DS, et al. Incidence and clinical characteristics of herpes zoster among children in the varicella vaccine era, 2005-2009. J Infect Dis 2013;208:1859-68. [CrossRef]

16. Gnann JW Jr, Whitley RJ. Clinical practice. Herpes zoster. N Engl J Med 2002;347:340-6. [CrossRef]

17. Dworkin RH, Johnson RW, Breuer J, et al. Recommendations for the management of herpes zoster. Clin Infect Dis 2007;44(Suppl 1):S1-26.

18. Whitley RJ. Approaches to the treatment of varicella-zoster virus infections. Contrib Microbiol 1999;3:158-72. [CrossRef] 